\title{
First record of common bottlenose dolphin (Tursiops truncatus) in Canadian Pacific waters
}

\author{
Luke R. Halpin ${ }^{1,2^{*}}$ (D) Jared R. Towers ${ }^{3,4}$ and John K. B. Ford ${ }^{4}$
}

\begin{abstract}
Background: Common bottlenose dolphins (Tursiops truncatus) are distributed globally in tropical and warmtemperate waters with coastal and offshore ecotypes known. In the eastern North Pacific Ocean, common bottlenose dolphins are typically found in offshore waters as far as $41^{\circ} \mathrm{N}$ and in coastal waters as far as $38^{\circ} \mathrm{N}$. Despite considerable survey effort, the species has not been previously recorded in Canadian Pacific waters.

Results: On 29 July 2017, a group of approximately 200 common bottlenose dolphins were observed together with approximately 70 false killer whales (Pseudorca crassidens) in waters of $16.5^{\circ} \mathrm{C}$ at $50^{\circ} \mathrm{N}$ during a pelagic seabird and marine mammal survey off the west coast of northern Vancouver Island, British Columbia, Canada.

Conclusions: This sighting represents the only occurrence of common bottlenose dolphins recorded in Canadian Pacific waters and, to our knowledge, is the most northerly record for this species in the eastern North Pacific. It is also the first sighting record of false killer whales in non-coastal waters in British Columbia, Canada. The occurrence of both species may be associated with a prolonged period of warming in offshore regions of the eastern North Pacific.
\end{abstract}

Keywords: Tursiops truncatus, Common bottlenose dolphin, British Columbia, Pseudorca crassidens, False killer whale, Distribution, Cetaceans

\section{Background}

The common bottlenose dolphin (Tursiops truncatus) is distributed widely in tropical and temperate waters of the North and South Pacific, Atlantic and Indian Oceans (Jefferson et al. 2015). Bottlenose dolphins were originally recognized as one species, but have been split into T. truncatus - the common bottlenose dolphin - and $T$. aduncus - the Indo-Pacific bottlenose dolphin, which is typically found in warm-temperate and tropical waters of the Indian and western Pacific Oceans (Jefferson et al. 2015). T. truncatus is a relatively large, robust and unmistakable dolphin most often found in groups of less than 20 animals. Large herds, although rare, can occasionally be seen in offshore areas (Wells and Scott 2018). The species is well-known to occur in mixed-

\footnotetext{
* Correspondence: LukeHalpin@gmail.com

${ }^{1}$ Halpin Wildlife Research, Vancouver, British Columbia, Canada

${ }^{2}$ Current address: School of Biological Sciences, Monash University,

Melbourne, Victoria, Australia

Full list of author information is available at the end of the article
}

species groups and for its social interactions with other cetaceans, including large whales as well as other dolphins (Jefferson et al. 2015).

Genetic differentiation between populations of coastal and offshore common bottlenose dolphins is well known throughout the species' global range (Hoelzel et al. 1998). In the eastern North Pacific two ecotypes of common bottlenose dolphin are recognized: a coastal ecotype is typically found in coastal waters (i.e. $<1 \mathrm{~km}$ from shore) from Ensenada, Mexico $\left(31^{\circ} \mathrm{N}\right)$ in the south to as far north as San Francisco (38 N) (Bearzi 2005; Carretta et al. 1998; Defran et al. 1999); and an offshore ecotype is typically found in offshore waters (i.e. $>1 \mathrm{~km}$ from shore) as far north as $41^{\circ} \mathrm{N}$ (Bearzi et al. 2009; Defran and Weller 1999).

The coastal population in United States Pacific coastal waters is estimated to contain at least 450 individuals and the offshore population is estimated at 3,495 individuals (Perrin et al. 2011). The California coastal population was documented to undergo a northerly range 
extension from southern to central California associated with warm water influx after the 1982-83 El Niño event (Wells et al. 1990). Ship-based line-transect cetacean surveys off the United States west coast have infrequently documented the offshore population off northern California (Barlow 2016). Only three common bottlenose dolphins have been observed alive further north in the eastern North Pacific. These occurred in Puget Sound, northern Washington State - one in summer 2010, another in winter 2010-2011 (Cascadia Research Collective 2011). Both animals subsequently stranded dead and their carcasses were recovered. In September 2017, a third animal was observed close to shore, traveling south near Apple Cove Point in Kingston, Washington State (Frey, unpublished observation). Two other strandings of this species have also occurred in northern Washington - one near Sequim in the Strait of Juan de Fuca in 2004 (Cascadia Research Collective 2011) and another in Samish Bay in 1988 (Ferrero and Tsunoda 1989). The latter individual was verified as belonging to the coastal population and is the most northerly record of this species in the eastern North Pacific. These sightings and strandings involved single individuals of this typically group-living species and were most likely vagrant or accidental occurrences.

Despite considerable ship-based and aerial survey effort for cetaceans off remote regions of British Columbia's outer and inner coast (Ford et al. 2010; Nichol et al. 2017; Williams and Thomas 2007), and high volumes of commercial and recreational whale-watching traffic off British Columbia's southern coast, no common bottlenose dolphins have been previously documented off Canada's west coast (Ford 2014). However, on 29 July 2017 an unusually large mixed-species aggregation of toothed cetaceans including common bottlenose dolphins and false killer whales was observed in British Columbia waters.

\section{Methods}

LRH sighted the animals during routine pelagic seabird and marine mammal surveys aboard the Canadian Coast Guard ship John P. Tully - a $69 \mathrm{~m}$ offshore oceanographic science vessel. The initial sighting was made by naked eye from the ship's wheelhouse at a distance of approximately $3000 \mathrm{~m}$ from the ship's stern, and later using Swarovski $8.5 \times 42$ binoculars. Photographs were taken with a Canon EOS 7D digital camera fitted with a $400 \mathrm{~mm} \mathrm{f} / 5.6$ Canon lens.

\section{Results}

Approximately 200 apparently healthy bottlenose dolphins of mixed age classes were observed traveling in an aggregation with approximately 70 false killer whales (Pseudorca crassidens) at 06:45 a.m. on 29 July 2017 (Fig. 1). Soon after the initial sighting, the herd approached the ship at a distance of not closer than 400 $\mathrm{m}$, at which point the John P. Tully was stopped. The animals were observed approximately $180 \mathrm{~km}$ (sighting location: $50^{\circ} 16.03^{\prime} \mathrm{N}, 130^{\circ} 51.22^{\prime} \mathrm{W}$, Fig. 2) offshore of
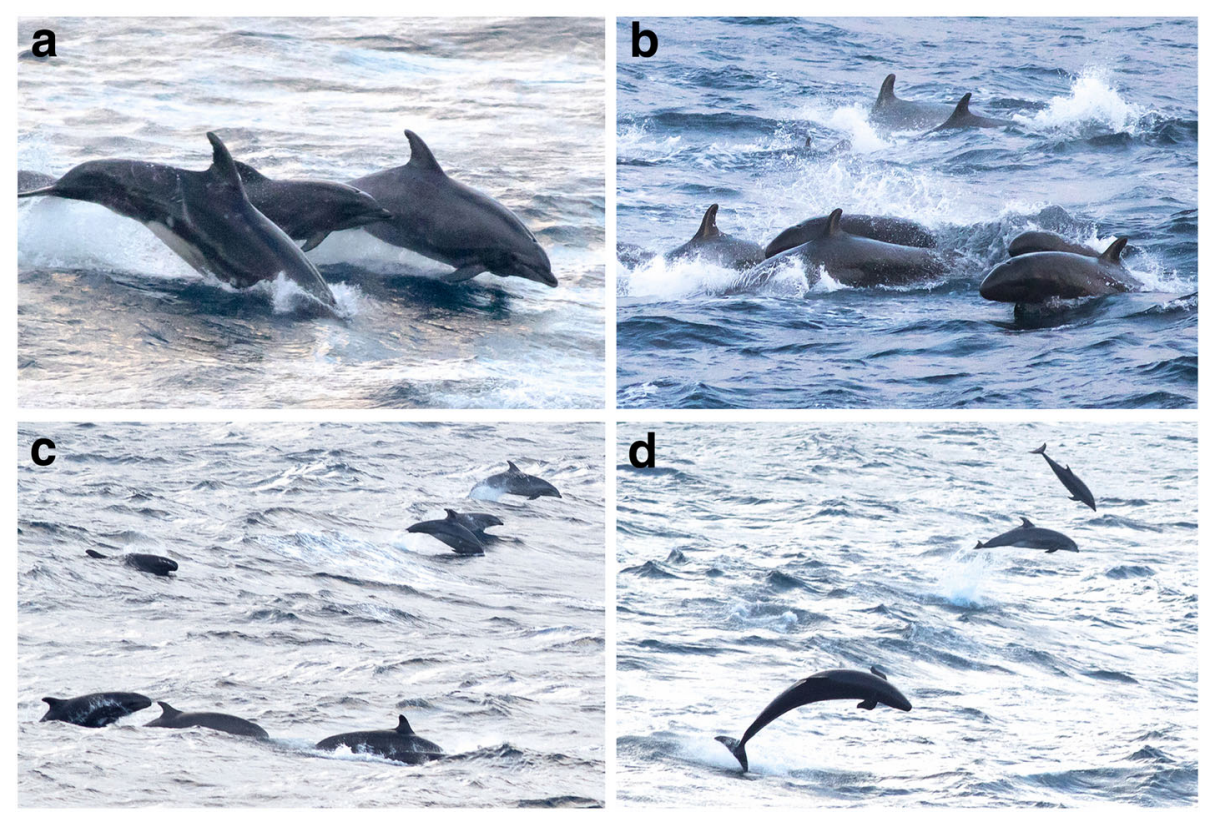

Fig 1 Common bottlenose dolphins (Tursiops truncatus) (a, background c, d) observed on 29 July 2017 in British Columbia waters. Individuals show identifiable morphological characteristics such as short to moderate-length beak, distinctly separated from the melon; gently curved mouth line, dipping downward from the tip of the beak and upwards at the base, and tall, falcate dorsal fins. False killer whales (Pseudorca crassidens) (b, foreground c, d). Photo: L. Halpin. 
the northwest coast of Vancouver Island and to the south of Delwood Seamounts in waters with a depth of $>2500 \mathrm{~m}$. Sea surface temperature at the time and location of the sighting, as recorded by the John P. Tully at a depth of $4.5 \mathrm{~m}$ was $16.5^{\circ} \mathrm{C}$.

Five northern right whale dolphins (Lissodelphis borealis) were also observed, but did not appear to be socializing nor traveling closely within the larger aggregation of bottlenose dolphins and false killer whales that appeared more tightly grouped. The northern right whale dolphins tended to remain approximately $100 \mathrm{~m}$ distance from the common bottlenose dolphins and false killer whales. The animals within the large aggregation were mostly traveling fast, breaching often and porpoising, but they occasionally slowed down or stopped and were spyhopping at regular intervals throughout the encounter, which lasted approximately 40 minutes. By approximately 07:25 a.m. the herd had traveled out of sight.

Several morphological features, detailed in Jefferson et al. (2015), were used for positive identification of the common bottlenose dolphins including: a short to moderate-length stocky beak distinctly separated from the melon by a distinct crease; a gently curved mouth line that dips downward from the tip of the beak and back upwards again to form what some say resembles a smile; tall and falcate dorsal fin that is central to the back; recurved and somewhat pointed flippers. Body color varied, but was generally light grey to almost black on the back and sides, fading to white on the belly. Additionally, that the individuals were traveling in a mixed- species group provided an additional behavioral clue to support positive identification of the species.

\section{Discussion}

This sighting of a large group of common bottlenose dolphins off the northwest coast of Vancouver Island is the first confirmed occurrence of the species in Canadian Pacific waters despite significant aerial and ship-based survey effort over the past 15 years (Ford et al. 2010; Nichol et al. 2017; Williams and Thomas 2007). There are also no stranding records for the species in British Columbia (Ford 2014). The location of this sighting is approximately $1000 \mathrm{~km}$ north of the typical range of common bottlenose dolphins off the west coast of North America, and represents the northernmost record of the species in the eastern North Pacific. An estimated 200 dolphins were present in this group, which is an unusually large aggregation - group sizes of both inshore and offshore ecotypes of the species off California typically average 10-20 animals and large aggregations occur in offshore waters (Wells and Scott 2018; Barlow 2016; Jefferson et al. 2015; Defran and Weller 1999). Considering that the common bottlenose dolphins reported in the present study were observed offshore traveling closely with false killer whales, a typically offshore species, they likely represent the offshore North Pacific ecotype. However, in the absence of genetic analysis, the ecotype of the dolphins in the present study remains speculative.

The presence of a large group of false killer whales mixed with these common bottlenose dolphins is a

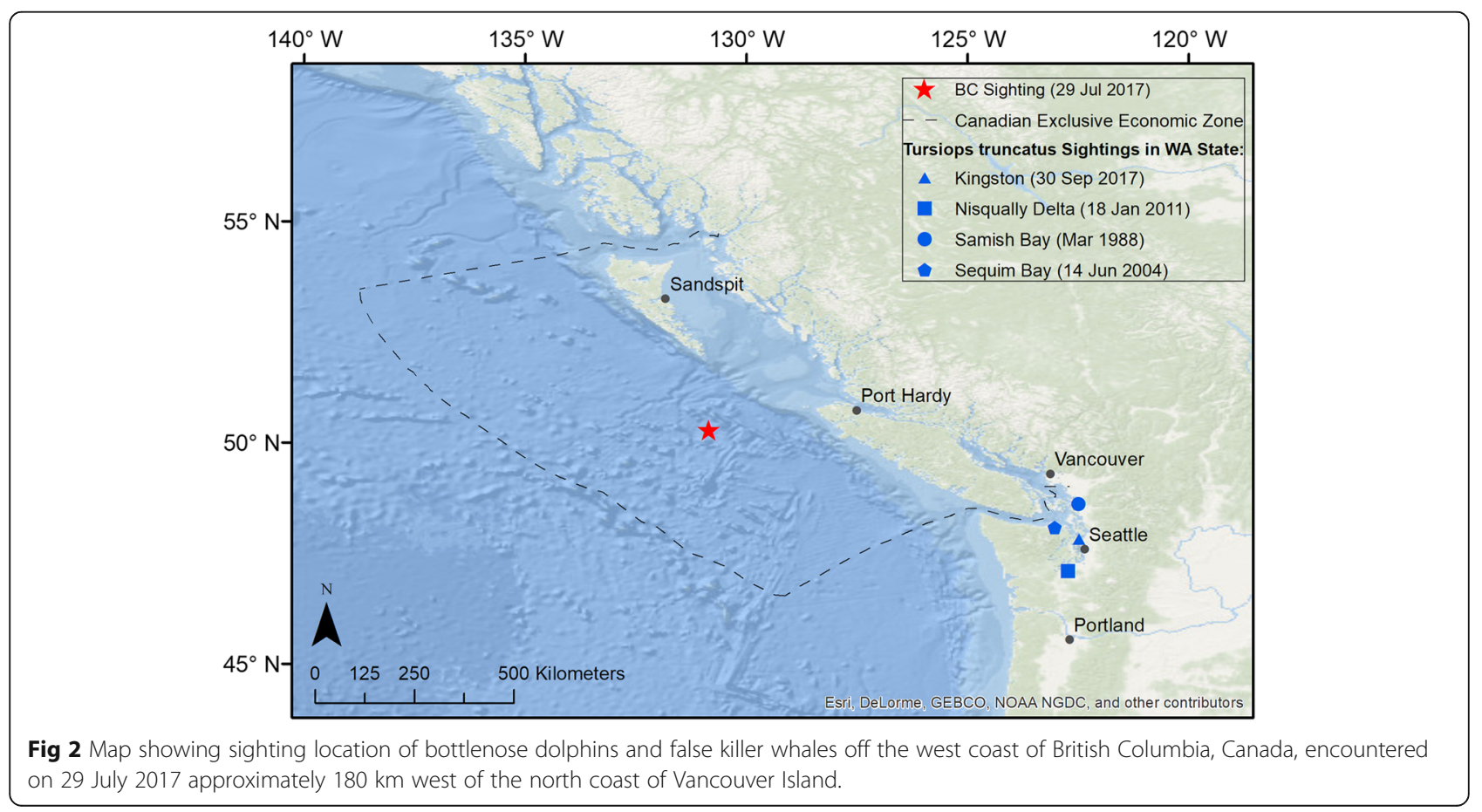


significant record for that species as well. False killer whales are a warm-temperate to tropical species that occurs mostly in deep, offshore waters. In the eastern North Pacific, false killer whales typically do not range north of $35^{\circ} \mathrm{N}$ (Chivers et al. 2007). The species was not recorded during a series of extensive cetacean surveys undertaken off the United States mainland west coast from California to Washington State during 1996-2014 (Barlow 2016; Barlow and Forney 2007). In Canadian Pacific waters, there are numerous sighting records of false killer whales, but most are related to a single group of about a dozen animals that entered inshore waters of southern British Columbia in 1987 (Ford 2014). Otherwise, the only other records of false killer whales in the Canadian Pacific are a single neonate that was livestranded along the west coast of Vancouver Island in July 2014 (Laanela 2014), and whistles characteristic of the species were detected on a recording instrument off the northwest coast of Vancouver Island in August and September, 2010 (Ford 2014).

Other species primarily known from warm waters south of B.C., such as short-beaked common dolphin (Delphinus delphis) and long-beaked common dolphin (D. capensis), dwarf sperm whale (Kogia sima), pygmy sperm whale (K. breviceps), and short-finned pilot whale (Globicephala macrorhynchus) have also occasionally been documented in the province (Ford 2014). However, the occurrence of these species is rare and, like common bottlenose dolphins and false killer whales, they can be considered vagrant, accidental or associated with changing ocean conditions, for example, due to climate change.

\section{Conclusions}

This sighting of common bottlenose dolphins and false killer whales follows a warming trend in eastern North Pacific waters from 2013-2016 that resulted in a variety of extralimital marine species records and ecosystem disturbances (Bond et al. 2015; Gentemann et al. 2017). The ocean warming trend in the Pacific appeared to continue into July with anomalous warmth of up to $1.7^{\circ} \mathrm{C}$ in July throughout the North Pacific (NOAA 2017).

Common bottlenose dolphins and false killer whales typically inhabit warm temperate waters in lower latitudes of the eastern North Pacific, but this sighting indicates that they will naturally range into British Columbia, Canada when oceanic conditions provide suitable habitat. This sighting occurred several months after a prolonged warming period and may represent ecosystem changes associated with that event.

\section{Acknowledgements}

We thank Fisheries and Oceans Canada and the captain and crew of the Canadian Coast Guard ship John P. Tully for facilitating this sighting. We also thank Robert Pitman for his assistance in confirming the species identification, and S Frey for providing information about an additional common bottlenose dolphin sighting.

\section{Funding}

This record was observed while conducting seabird and marine mammal surveys for the Canadian Wildlife Service of Environment and Climate Change Canada, as part of a collaborative research initiative led by Fisheries and Oceans Canada, to study unexplored seamounts off Canada's west coast.

\section{Availability of data and materials}

Additional photographs from the current study are available from the corresponding author on reasonable request.

\section{Authors' contributions}

$\mathrm{LRH}$ conducted the fieldwork, analyzed photographs and prepared the manuscript. JT and JKBF analysed the photos, collated additional records, and assisted with preparing the manuscript. All authors read and approved the final manuscript

\section{Ethics approval and consent to participate}

Not applicable.

\section{Competing interests}

The authors declare that they have no competing interests.

\section{Publisher's Note}

Springer Nature remains neutral with regard to jurisdictional claims in published maps and institutional affiliations.

\section{Author details}

${ }^{1}$ Halpin Wildlife Research, Vancouver, British Columbia, Canada. ${ }^{2}$ Current address: School of Biological Sciences, Monash University, Melbourne, Victoria, Australia. ${ }^{3}$ Bay Cetology, Alert Bay, British Columbia, Canada.

${ }^{4}$ Fisheries and Oceans Canada, Pacific Biological Station, Nanaimo, British Columbia, Canada.

Received: 6 October 2017 Accepted: 26 February 2018

Published online: 20 April 2018

\section{References}

Barlow J. Cetacean abundance in the California current estimated from ship-based line-transect surveys in 1991-2014. Southwest Fisheries Science Center, Administrative Report LJ-2016-01. 2016.

Barlow J, Forney KA. Abundance and population density of cetaceans in the California Current ecosystem. Fish. Bull. 2007;105(4):509-26.

Bearzi M. Habitat partitioning by three species of dolphins in Santa Monica Bay, California. Bull. South. Calif. Acad. Sci. 2005;104(3):113-24.

Bearzi M, Saylan CA, Hwang A. Ecology and comparison of coastal and offshore bottlenose dolphins (Tursiops truncatus) in California. Mar. Freshwater Res. 2009;60(6):584-93.

Bond NA, Cronin MF, Freeland H, Mantua N. Causes and impacts of the 2014 warm anomaly in the NE Pacific. Geophys. Res. Lett. 2015;42(9):3414-20.

Carretta JV, Forney KA, Laake JL. Abundance of southern California coastal bottlenose dolphins estimated from tandem aerial surveys. Mar. Mammal Sci. 1998;14(4):655-75.

Cascadia Research Collective. Bottlenose dolphin stranding in Puget Sound (February, 2011). 2011. http://www.cascadiaresearch.org/projects/strandingresponse/bottlenose-dolphin-stranding-puget-sound-february-2011. Accessed 22 Aug 2017

Chivers SJ, Baird RW, McSweeney DJ, Webster DL, Hedrick NM, Salinas JC. Genetic variation and evidence for population structure in eastern North Pacific false killer whales (Pseudorca crassidens). Can. J. Zool. 2007;85(7):783-94.

Defran $\mathrm{RH}$, Weller DW. Occurrence, distribution, site fidelity, and school size of bottlenose dolphins (Tursiops truncatus) off San Diego, California. Mar. Mammal Sci. 1999;15:366-80.

Defran RH, Weller DW, Kelly DL, Espinosa MA. Range characteristics of Pacific coast bottlenose dolphins (Tursiops truncatus) in the Southern California Bight. Mar. Mammal Sci. 1999;15(2):381-93.

Ferrero RC, Tsunoda LM. First record of a bottlenose dolphin (Tursiops truncatus) in Washington state. Mar. Mammal Sci. 1989:5(3):302-5.

Ford JKB. Marine Mammals of British Columbia. Royal BC Museum: Victoria; 2014. 
Ford JKB, Abernethy RM, Phillips AV, Calambokidis J, Ellis GM, Nichol LM. Distribution and relative abundance of cetaceans in western Canadian waters from ship surveys. Canadian Technical Report of Fisheries and Aquatic Sciences. 2010;2913:2002-8.

Gentemann CL, Fewings MR, García-Reyes M. Satellite sea surface temperatures along the West Coast of the United States during the 2014-2016 northeast Pacific marine heat wave. Geophys. Res. Lett. 2017;44(1):312-9.

Hoelzel AR, Potter CW, Best PB. Genetic differentiation between parapatric 'nearshore'and 'offshore'populations of the bottlenose dolphin. Proc. R. Soc. Lond. B. 1998;265(1402):1177-83.

Jefferson TA, Webber MA, Pitman RL. Marine mammals of the world: a comprehensive guide to their identification. 2nd ed. London: Academic Press; 2015.

Laanela M. False killer whale calf recovering at Vancouver rescue center. CBC News. 2014; Available from: http://www.cbc.ca/news/canada/britishcolumbia/false-killer-whale-calf-recovering-at-vancouver-rescue-centre-1. 2703713. Accessed 10 Jul 2017

Nichol LM, Wright BM, O'Hara P, Ford JKB. Risk of lethal vessel strikes to humpback and fin whales off the west coast of Vancouver Island, Canada. Endanger. Species Res. 2017;32(1):373-90.

NOAA National Centers for Environmental Information, State of the Climate: Global Climate Report for July 2017. 2017. https://www.ncdc.noaa.gov/sotc/ global/201707. Accessed 26 Sep 2017

Perrin WF, Thieleking JL, Walker WA, Archer Fl, Robertson KM. Common bottlenose dolphins (Tursiops truncatus) in California waters: Cranial differentiation of coastal and offshore ecotypes. Mar. Mammal Sci. 2011;27:769-92.

Wells RS, Hansen LJ, Baldridge A, Dohl TP, Kelly DL, Defran RH. Northward extension of the range of Bottlenose Dolphins along the California coast. In: Leatherwood S, Reeves RR, editors. The Bottlenose Dolphin. San Diego: Academic Press; 1990. p. 421-31.

Wells RS, Scott MD. Bottlenose Dolphin, Tursiops truncatus, Common Bottlenose Dolphin. In: Würsig B, Thewissen JGM, Kovacs KM, editors. Encyclopedia of Marine MammalsThird Edition. San Diego: Academic Press; 2018. p. 118-25.

Williams R, Thomas L. Distribution and abundance of marine mammals in the coastal waters of British Columbia, Canada. J. Cetacean. Res. Manag. 2007;9(1):15-28.

\section{Submit your next manuscript to BioMed Central and we will help you at every step:}

- We accept pre-submission inquiries

- Our selector tool helps you to find the most relevant journal

- We provide round the clock customer support

- Convenient online submission

- Thorough peer review

- Inclusion in PubMed and all major indexing services

- Maximum visibility for your research

Submit your manuscript at www.biomedcentral.com/submit 